\title{
The Language of Street Children: A Sociolinguistic Study in the Regency of Klaten, Central Java
}

\author{
Prembayun Miji Lestari \\ Faculty of Languages and Arts \\ State University of Semarang \\ Sekaran Campus, Gunung Pati, Semarang \\ prembayun@gmail.com
}

\begin{abstract}
The object of this study is the Street Children in the region of Klaten, particularly in the area of Klaten. The purpose of this study is to determine how do the language variations and the characteristics of the communities of street children related to the contemporary multicultural culture. The data is obtained from direct observation which is taken from daily conversation. The data collection is collected by tapping/recording techniques, 'Simak Bebas Libat Cakap' technique (Uninvolved Conversation Observation Technique), 'Simak Libat Cakap' (involved conversation observation Technique), taking notes and recording technique. The result is the discovery of a unique variety of language in the community of Street Children, the more usage of the Javanese particularly Ngoko Lugu level of speech containing "Pisuhan" (words of profanity) and insults.
\end{abstract}

Keywords: Street Children Community , unique characteristics, "Pisuhan" (words of profanity) and insults.

\footnotetext{
Abstrak

Obyek penelitian ini adalah anak-anak jalan di Kabupaten Klaten,khususnya di daerah Klaten kota. Tujuan penelitian ini adalah untuk mengetahui dan mendeskripsikan variasi bahasa dan karakteristik
} 
komunitas anak jalanan terkait dengan budaya multi-kultural kontemporer. Data tersebut diperoleh dari observasi langsung yang diambil dari percakapan sehari-hari. Pengumpulan data dikumpulkan dengan teknik merekam, 'Simak Bebas Libat Cakap' technique (Uninvolved Conversation Observation Technique), 'Simak Libat Cakap' (Involved Conversation Observation Technique), pencatatan dan perekaman. Hasil penelitian ini ialah penemuan adanya keunikan berbahasa dalam komunitas Anak Jalanan, ragam tingkat tutur Jawa Ngoko khususnya tingkat Lugu yang berisi "Pisuhan" (kata-kata tidak senonoh) dan penghinaan.

Kata Kunci: Komunitas Anak Jalanan, Karakter yang Unik, , "Pisuhan" (kata-kata makian) dan Penghinaan

\section{Introduction}

In accordance with one of the dynamic natures of language, it is inseparated from the range of possible changes which may occur at any time. Similarly, the language of a community cannot be separated from it. In a multicultural society, it appears many regional variations of certain social groups. Linguistic diversity is influenced by age, educational level, gender, socio-economic status, profession, and origin of place.

One of the diversities which appears in society is the language of the street children. It is a part of a community language, which has special characteristics in its use. The emergence of language variation in the community of street children cannot be separated from the multicultural background they are dealing with and the influence of mass media and television which give effects on their linguistic experience. It is interesting to study further since the condition of language that occurs in the community of street children vary in line with the changing times.

Problem Statement in this study relates to the social phenomena 
associated with the usage of language of street children in Klaten bus terminal. The formulation of the problem in detail can be described as how language is used by Street Children in Klaten bus terminal and What the characteristics of the language are used by Street Children in the Regency of Klaten.

\section{Previous research}

Several previous studies that relate to this the formulation of these research problems can be categorized as a sociolinguistic study. The following researches examine linguistic variations in language as used by the users in their society. Those are conducted by Berman (1998), Triyoga Utami Dharma (2004), Noviani (2004), and Prembayun Miji Lestari (2010). Furthermore, a study evaluating the diversity of languages is done by Gumperz. The other studies which have relation with the diversity of language use: Errington (1985), Suwito (1987), Markhamah (2000), and Kundharu Sadhono (2003).

Berman (Triyoga in 2004: 19) in his study entitled Speaking through the Silence: Narratives, Social Conventions, and Power in Java found some problems related to the language used by "Wong Cilik" ( the grassroots represented by women factory workers in Yogyakarta) as influenced by the sustained values in Javanese community. Javanese women had the tendency to show more reticence as the philosophy of nrima (the attitude of acceptance/surrender) to the prevailing conditions in Javanese community.

The similar research was the research of Triyoga Utami Dharma (2004). She concludes that 1) the existing social relations between the speakers and hearers are able to determine the use of community 
languages of Klewer market traders with the Javanese and non-Javanese hearers; 2) the discovery of two registers in the use of everyday language community ethnic Javanese traders in the market Klewer Sala namely social activities and register in the register in trading activities; 3) the determinants of the merchant community of ethnic language use Java to interact with mira said ethnic Javanese and non-Java language and fakor consists of non-language.

Noviani (2004) explains that the form of slang used by Street Children in the city of Semarang is in the form of single words and complex. The process of these word formation has undergone some process such as 1) the creation of new words with new meanings, 2) borrowing words of local and foreign language, 3) affixation, 4) shortening, 5) reduplication, and 6) compounding. While the functions of the use of slang language among Street Children in Semarang city are to familiarize, to conceal the secret, to invite, to convey emotions or feelings, joke, advises, threats, mocks, curses and commands.

Prembayun Miji Lestari (2010) reports that the use of the language of street musicians has particular characteristics and cannot be separated from the three forms of interaction: internal interactions, external interactions, and mixed interactions. It was found there were code mixing, code switching, the informal variety of language which was characterized by the presence of the language of syncope and aphaeresis. Besides, it was found the forms of register within the society of street musicians such as: pengamen ngampung, pengamen estafet, babi Arab, sepur kelinci, genthong, hongkong, brompit, brompit peluk, sektor, operasi, and other forms of registers.

Suwito (1987) in his study entitled Berbahasa dalam Situasi 
Diglosik: Kajian tentang Kendala Pemilihan dan Pemilahan Bahasa di dalam Masyarakat Tutur Jawa di Tiga Kelurahan di Kotamadya Surakarta The use of language in a diglosic Speaking Situations: A Study of Constraints of language selection in Javanese speaker community in three village in the municipality of Surakarta, elaborated that the tendency of the citizen of the city of Sala in distinguishing the use of Javanese and Indonesian was based on social, cultural, and situational factors. The use of both languages are not mutually influencing one another even though the use of the Javanese is able to form bilinguality and multilinguality.

Markhamah (2000) shows that there is a close connection between the use of Javanese language and ethnicity. The Ethnic of Chinese as the part of the City of Sala has a variety of language in making their interaction with the hearer. However, they still keep their attitudes to maintain their culture, so that the use of Javanese is limited in use it is just as a mediating language to interact with speakers of Javanese society. The specificity of the Javanese use of the ethnic of Chinese can be shown in the interference, code switching and borrowing.

Furthermore, Kundharu Saddhono (2003) reports that the habit of using the language used in the Madurese ethnic in Surakarta depends on the existing circumstances and situations, to whom they talk to has a great influence for the choice of language they used. There are at least three choices of languages used by the ethnic of Madurese living in Surakarta, Madurese, Javanese, and Indonesian.

Both study conducted by Kundharu and Markhamah had provided a more powerful depiction dealing with the use of the Javanese language in the multi-ethnic societies in the region of Surakarta. The above 
numerous studies have given a great contribution in providing the direction and rationale for researcher in understanding the usage of language in a particular speaker's community.

\section{Street Children As a Speech Community}

Street children are individuals under 18 years old who spent some or most of their time on the streets in order to perform their activities in the aim of earning money or sustaining life. The context of "Jalanan" or "The streets" here not only refers to the places like streets, but it also leads to crowded places such as bus terminals, railway stations, markets, shopping centers, parks, and squares (Saladin, 2000:13).

In sociolinguistic conception of Dell Hymes, there is no explicit distinction between language as a system and speaking as a skills. Both refers to communicative skills or communicative competence. Communicative ability covers language skills possessed by the speakers along with their skills in expressing language in accordance with the functions and settings and its usage in the context of social norms.

Communicative ability owned by both individual and group is called Verbal Repertoire. Verbal Repertoire can be categorized twofold, namely the Verbal Repertoire of the individual and community-owned. If a community has a relatively equal Verbal Repertoire and has the same appreciation of the usage of the language in their society it is called Masyarakat Bahasa (Speech community). Suwito and Kloss (in the DepDikBud, 1995: 163) states that speech community is all the speakers of a language who have the same mother tongue and particular system of language. In other words, a language reflects the social identities of speakers, whereas their speech is a speech signal of social identity. Based 
on the verbal repertoire owned by the people, Speech Community is divided into threefold, namely monolingual (one language), bilingual (two languages), multilingual (more than two languages).

Based on the above description, it can be concluded that the group of Street Children who were the subject of this study is one of speech community since it uses the same system of language signs and has the same paradigm to the norms of language usage. In this case, Street Children belongs to Speech Community which has a variety of language characterized by features of mutual understanding (Mutual Intelligibility). The existence of this aspect of mutual understanding leads to smooth communication running in line with the expectation and successful conveyed message.

\section{Language variation}

Language variation is caused by the existence of social interaction activities which is underwent by the society or a very diverse social groups whose speakers are not homogeneous. In terms of language variation, there are two views. The first, variation is seen as a result of social diversity of language speakers and the variety of language functions. So the language variation that occurs as a result of social diversity and the diversity of language functions. The second, the language variation which had already exists in the aim of fulfilling its function as a means of interaction in a wide range of community activities. However, Halliday distinguishes language variation based on the language user (dialect) and the language usage (register). Chaer (2004:62) said that the language variation at the initial was distinguished by its speakers and language users. 


\section{Code switching}

Code Switching is the lingual occurrence of switching or transition from one code to another code. For example, a particular language speaker is using Bahasa then he is switching to use the Java language. Code switching is one aspect of language dependency (dependency language) in a multilingual society. In a multilingual society it is very difficult for a speaker to absolutely uses only one language. In code switching each language tends to support each function and each function should be in accordance to the lingual context. Appel gives a definition of code switching as the tendency of language switching usage since there is a change in circumstances. Suwito divides over code switching twofold: 1) extreme code switching: code switching such as switching from Indonesian to English or vice versa and 2) internal code switching: the code switching in a form of variant switching, such as from the Java language ngoko then changes into Krama( Javanese honorific level of speech).

\section{Code mixing}

Code Mixing occurs when a speaker's of language dominantly uses a language supporting utterances which is interspersed with elements of another language. It is usually associated with the characteristics of speakers, such as social background, level of education and religious spirit. The distinctive characteristic is in a form of relax conversation within an informal situation. This happened since there is a poor or limited vocabulary of a particular language, the expression on the language has no equivalence, so the language speakers were forced to use another language, although it only supports a single function. Code 
Mixing belongs to linguistic convergence. The background of code mixing can be classified into two types: the attitudes (attitudinal type) and the background of the attitude of the speakers.

\section{Research Methodology}

The analysis of problems in this study used theoretical and methodological approaches. The theoretical approach used in this study is the sociolinguistic approach, the approach of the research related to the theories or language theories in relation to the community or society (Chaer and Agustina 1995: 3). The Methodological approach used was qualitative descriptive approach. In this study, the researcher describes the use of the language of Street Children in the regency of Klaten.

The source of research data is the usage of the language of Street Children, especially the street musicians who are members of the community of MUAT (Musisi Anak Jalanan Terminal Klaten or The Street Musicians of Street Children of Klaten Bus Terminal) and Street Vendors. The setting of the place of research was in the bus terminal due to the fact that it is a central gathering place for Street Children.

The techniques used in collecting data of this study were (1) technique of tapping or recording technique in order to obtain a natural conversation; (2) Teknik Simak Bebas Libat Cakap or technique which was used to observe the speech used by Street Children when they communicate but the researcher did not participate in the conversation of Street Children in order to get natural conversation; (3) Simak Libat Cakap (Involved Conversation Observation Technique) which means that the researcher involved in the process of conversation which of Street Children in the Klaten bus terminal; (4) Recording Technique which was 
done using handycam; (5) Taking Note Technique or changing the recording data into written data. The data are grouped based on type of the use of language and context of the conversation.

\section{Discussion}

\section{The use of language of street children in Klaten bus terminal}

The language used by Street Children community in Klaten bus terminal in their communication is mostly in the form of Javanese Ngoko and tends to use swearing words or Pisuhan. There is also possibility of mixing Javanese-Indonesian and even foreign language vocabularies. The use of Street Children was characterized by the use of informal language which is influenced by social background of Javanese cultural context.

The code chosen by the community of street children depends on the type of people they encounter. If they communicate with strangers, they very often prefer to use Indonesian rather than Javanese. This is done to respect others and make communication more neutral.

A person who masters two or more languages will face problems when she/he chooses language to use when she/he communicates with others. The phenomena can be found within the community of Street Children in Klaten bus terminal. In fact, there are three types of code choices: (1) using the same language variation; (2) using code switching or using one language on one purpose, and using another language for other purposes; (3) using code mixing which means using a particular language by mixing pieces of some languages. The followings elaborate the daily usage of Street Children speech community.

The use of Javanese language

The community of street children commonly use Javanese ngoko in 
their daily communication. All of the selected vocabulary usage is the usage of ngoko lugu words. The reason is because among the fellow members of the community are already familiar, there is no distance in communication. They tend to use impolite or vulgar Ngoko. More details data can be viewed on the following conversation.

(1) P: "Gandheng sak iki dina nyadran, diwenehi penumpang buah apel ya ra pa pa. (Since today is Nyadran day, if passengers give an apple it doesn't matter)

MT: "Kowe arep munggah ra, yu?" (you will get in the bus, won't you miss?)

P: "Rasah nyangkir, wayahe munggah ya munggah. Nak pengin dhisik, ya munggaha!'”(Don't talk too much, just get in the bus. If you wanna go first, please,go!)

MT: "ampak, nak ngana aku tak sik yo, yu? Kowe ngentenana limang-limang menit engkas." (Yes, if it is like that I will go first, miss? You just wait for five minutes)

P: "ampak kana dhisika, mengko nak ketangkep PII rasakna!" (Well, you may go there at first, you may feel misery if suddenly you have been caught by PII!)

(2) P: "Wit mau ampak munggah-munggah, kapan arep munggah kingko?" (What are you waiting for?, when will you get in the bus then?)

MT: "Durung munggah, yu?" (Haven't you get in the bus, Miss?)

P: "Lha piye le arep munggah. Lha ngadhek-ngadhek trus kok" (How can I get in the bus, There is no space left)

MT: Wah, saya awan saya kebak"( Well, the day is getting longer, it's (the bus) getting fuller)

P: "Kae LANGEN radha sela, takmunggah kae wae we. Lumayan nak entuk kena nggo nothol ro nggo tuku handphone black berry." (That LANGEN (bus) has somewhat less space, I'll take that. It's not bad if I can get (some money) to eat and buy blackberry)

Meanwhile, the community of street children use of Javanese language of Krama when they deal with other people or people outside 
their community. This was done to show a respect to the hearer. This can be seen in the following data.

(3) MT: “Nderek lenggah ya, om”(May I sit here, Sir?)

P: "Nggih, mangga..." (Yes, please ...).

The use of Indonesian

As it has been explained above, the community of street children use Bahasa (Indonesian) when they encounter strangers or the people outside their community as a tribute or a respect to the persons.

From the data obtained it can be found that the use of Indonesian by the community of street children is characterized by the dialect of Jakartan, for instance: Nyari, Nawarin. The following is the supporting data.

(4) P: "Mbak, dulu kuliah di mana?" ("Miss, where did you go for study?)

MT: "UNS, om" (UNS, Sir)

P: "Kosnya daerah mana, mbak?" (where was your boarding house, Miss?)

MT: "Awalnya di Jebres daerah Panggung, kemudian di daerah Ngoresan dekat RSJ, terus di Palur menjauh dari kampus" (At first I was in the area of Jebres, Panggung, then I moved to Ngoresan near RSJ (Mental Ilness Hospital), then I stayed in Palur -far away from campus)

P: "Nyari suasana baru ya, mbak?" (Looking for new atmosphere, Mbak?)

MT: "Ya, om" ("Yes, sir)

P: "Dulu saya jadi anak jalanan dengan pengamen KAPAS, tapi sejak satu tahun ini saya pindah ke Klaten. Ada yang nawarin, lalu saya gabung di MUAT. Makanya saya hapal daerah Solo, mbak. Daerah operasi saya dulu di Penggung, Jebres." (I used to be a street children with KAPAS Street musicians, but since the last year I moved to Klaten. There was someone offering me this, then I join 
MUAT. It's why I know Solo area very well, Miss. My working in the past was in Penggung, Jebres)

\section{The use of mixed languages}

The use of this mixed languages produces code mixing and code switching. From the data, it can be found that there is mixed language use of Javanese, Indonesian, English and Arabic. For instance, the use of English vocabulary words like "sorry", "shopping", "traveling", "Hand phone Blackberry", and etc. The use of Arabic words can be found in the expression of Astaghfirllahu Adhzim .

The use of this mixed language usually comes naturally. These foreign language terms which emerged in the language use of the community are usually common and familiar vocabulary used by the public.

The characteristic of the language of street children in Klaten Bus Terminal

The language characteristics of the community of Street Children are on the aspects of (1) a variety of oral language, (2) swearing words or Pisuhan, (3) the use of Language style, and (4) the specific vocabulary of the community of Street Children.

The variety of oral language of street children

In performing communication, the community of Street Children tend to use more verbal interaction. There are several characteristics of variety of oral language usage of Street Children:

a. Shortening (contraction)

Shortening or contraction is done by removing one part of the 
word, for example, (m-) engko (m-)engko (or later on), (ke-)piye (or how), (o-)ra (or no), (ing-)nggih (or yes), (a-)su (or dog (swearing word)), w(a)e (or only), d(huw)it (or money), (dhi-)sik (or go first), (a)wit' (or since), (i)ki (me)ngko (or later on) and etc.

This can be seen on the following data.

(5) "Kae sopire kaya ra nde dosa!" (The driver looks like innocent!)

(6) "Bocah bayi we kemaki” (You are just little kid but naughty)

(7) "Lha aku ngathung we ra entuk dit lho! Sik ngenteni Kramat." (I have held out my hands but I didn't earn money. I am waiting for Kramat)

(8) "Wit mau durung munggah-munggah, kapan arep munggah kingko?" (Why are you still staying here? When will you get in the bus?)

The use of shortened forms of speech as shown in the example above is a common things in the verbal and direct face-to-face communication. The shortening phenomenon is an evidence of the existence of restricted speech. Another form of shortening can be found in the following data:

$\begin{array}{lll}\text { pora } & \text { from } & \text { opo ora (it isn't)' } \\ \text { nggo } & \text { from } & \text { dinggo (to be used) } \\ \text { piye } & \text { from } & \text { kepiye (how) } \\ \text { wis } & \text { from } & \text { uwis (already) } \\ \text { bar } & \text { from } & \text { bubar (completed) } \\ \text { sih } & \text { from } & \text { isih (still) } \\ \text { ndanak } & \text { from } & \text { nduwe anak (having kids) } \\ \text { nde } & \text { from } & \text { nduwe (have) }\end{array}$


kingko from iki mengko (later on)

\section{b. Acronyms and abbreviations}

The acronym is a combination of letters or syllables which are written and commonly used to make easy and to make it effective dealing with the conversation in the community of Street Children particularly in Klaten bus terminal. In addition, the development of technology and mass media has a great influence on the language and vocabularies which emerge in the community of Street Children. It is undeniable that the slang language and sometimes Western nuanced words also appear in that community.

Gentholet as the acronym of gentho klelat-klelet (lazy criminal)

Pulkam is the acronym of "Pulang Kampung (Returning Home)

Gondes is the acronym of gondrong ndeso (the long-haired villager)

The following supporting data which shows the existence of an acronym, it can be found at the data code [9] and [10].

(9) P : “Ooo...dasar gentholet! Gondes, kowe!” (“Ooo...you're gentholet! Gondes")

(11) MT2:"Iya. Lha sing kantoran masih pada bolos menikmati mudik pulkam kok!" ("Yes. The blue collar workers are off enjoying their "mudik pulkam"(returning home")

Meanwhile, a commonly used acronyms for the community of Street Children take the first letter of every word. The examples of such abbreviations are: SST (Shopping-Shopping and Traveling), SSW (SorrySorry Wae), PII (the "wicked thugs" officials wearing black uniform), KAPAS (The Family of Street singers of Surakarta), MUAT (Child Street 
Musicians Klaten Terminal), KJ (Kramat Jati ), LJ (Langsung Jaya (bus name)), SH (Suharno (bus name)), PJ (Putra Jaya (bus name)), JP (Jaya Putra (bus name)), AJ (Anter Jaya (bus name)). The data (12), (13), (14), and (15) give valuable contexts:

(12) MT: "ampak, nak ngana aku tak sik yo, yu? Kowe ngentenana limang-limang menit engkas.”(“ Okay, I will go first, Miss? You just wait for five minutes")

P : “_ampak kana dhisika, mengko nak ketangkep PII rasakna!" ("Well, you may go at first, you will get trouble if PII catch you")

(13) MT : "Ora ngenteni LJ apa SH wae" ("Why don't you wait for LI or SH instead?

$\mathrm{P}$ : "Ora, KJ apa PJ wae" ("No, I am just waiting for KJ or $\mathrm{PJ})$

(14) P : "Waduh, penuh lagi, penuh lagi! Masak dari tadi bis penuh terus, kapan longgare?" ("Wow, it's full again! The busses are always full all the time, when are they free?")

MT1 :"Masih pada SST alias shopping-shopping and travelling, kaleee..." ("They are still having SST or ShoppingShopping And Traveling, may be..."

(15) MT2 : “Aku munggah sik yo, kae AJ teka. ”("I'll get in at first. $\mathrm{AJ}$ is coming.")

(16) P: "Dulu saya jadi anak jalanan dengan pengamen KAPAS, tapi sejak satu tahun ini saya pindah ke Klaten, gabung di MUAT. Makanya saya hapal daerah Solo, mbak. Daerah operasi saya dulu di Penggung, Jebres." ("I used to be a street children with KAPAS Street musicians, last year I moved to Klaten. There was someone offering me this, then I joined MUAT. It's why I know Solo area very well Miss. My working area was in Penggung, Jebres") 


\section{Code Mixing - Code Switching}

The usage of Street Children language is inseparable from the existence of the process of code mixing. This occurs because of the fast growing of cultural and linguistic technologies that affect the language behavior of the community. The following examples show the data that uses the lexicon of Bahasa (e.g. Gayamu Sok Suci (you just like a saint)), The Jakartan dialect (e.g. Nawarin (offering), Nyari (looking for)), English expressions (e.g. Sorry, Shopping, Shopping And Traveling, Mobile Black Berry) and Arabic (e.g. Astaghfirllahu Adzhim (Oh my God, Please forgive me)).

(17) P:" Walah...cangkem ngger marep ndhuwur ya kaya ngana kuwi! Gayamu sok suci!"” ("Oh my dear ... your talk is not proper and wise, you just like a saint!")

(18)MT: "Astaghfirllahu hal adzhim ... nyebut, yu, $y u \ldots$..."("Astaghfirllahu adzhim ... ask, Allah's forgiveness, Sister...!")

(19) P : : "Waduh, penuh lagi, penuh lagi! Masak dari tadi bis penuh terus, kapan longgare?" (" ("Wow, it's full again! The busses are always full all the time, when are they free?"?")

(20)MT1: "Masih pada SST alias shopping - shopping and travelling, kaleee..." ("They are still having their SST or Shopping-Shopping and Traveling, may be..."

The other data indicate the presence of Jakartan dialect as it can be seen in the following data.

(21) P: "Nyari suasana baru ya, mbak?" (Looking for new atmosphere , Miss?"

MT: "Ya, om" ("Yes, Sir")

P : "Dulu saya jadi anak jalanan dengan pengamen KAPAS, tapi sejak satu tahun ini saya pindah ke Klaten. Ada 
yang nawarin, lalu saya gabung di MUAT. Makanya saya hapal daerah Solo, mbak. Daerah operasi saya dulu di Penggung, Jebres." ("I used to be a street children with KAPAS Street musicians, last year I moved to Klaten. There was someone offering me this, then I joined MUAT. It's why I know Solo area very well Miss. My working area was in Penggung, Jebres")

While for code switching, It is switching from Bahasa to Javanese Krama.

(22) MT: "Lha pindah, kenapa om?" (Why did you move, Sir?)

$\mathrm{P}$ : "Sami kaliyan jenengan mbak, pados swasana enggal" ('Just like you,Sister, I'm looking for a new atmosphere")

MT: “O, gitu ceritanya, om..." ("Oh, I see, Sir")

$\mathrm{P}$ : "Iya, mbak" ("Yes,Sister")

Besides, in the variety of oral language, expressions of Sala dialect are often used by the community of Street Children, such as: ki ("this"), lho, ta, kok, no, we, lha and etc. The usage of Sala dialect is also frequently found on the process of communication using Indonesian language.

\section{The Use of Rude Language And "Pisuhan"(Swearing)}

Based on the research observation, the verbal interaction among the community of Street Children in the terminal of Klaten was dominated by rude language and swearing. They usThe languageually communicate in Javanese ngoko (informal language). This is used in everyday communication in order to be familiar and break the edges among them. Sometimes they also mix other languages (such as Indonesian, Arabic and English), eventhough the Javanese ngoko still dominate. 
(23) P: "Ngapa mlorok ngulatke aku, su! "'“Why do you stare at me, doggy (swearing word like bastard)?'

MT: "Sapa sing ngulatke kowe, su! SSW, sorry-sorry wae lah yauww" ("Who's looking at you, doggy! SSW, it's a pity and shame on you")

$\mathrm{P}$ : "Bocah bayi we kemaki!'”(you are naughty boy)

MT: "Ben, tho!" (I don't care!)

P :"Ooo...dasar gentholet! Gondes, kowe!"

The above data contains a conversation between an 18 years old senior street singer as the speaker $(\mathrm{P})$ and the $17^{\text {th }}$ junior street singer as the speaking partner (MT). Both of them have a quarrel so that the words they uttered is rude words which contain words of profanity. This was indicated by the usage of the word "Asu" which is shortened by the use of the word " $S u$ " or 'dog'. The next one is the use of the sentence "Bocah bayi we kemaki" and the sentence "Ooo.. dasar gentholet! Gondhes kowe!" Those are forms of abuse to show the feeling of resentment. In addition, the sentence contains the elements of underestimating his partner speaker. The word 'mlorok' "melirik" ("pierce," "sharp glance") is one of the rude or profane lexicon.

The other frequent profanity language which emerged in the conversation are: anjing (dog), kirik (puppy), kucing (cat), matamu (your eyes), monyet (monkey), wedhus gibas (sheep), diancuk, setan (satan), iblis (devil), ndasmu (your head). The other profanity words are mostly from the names of animals and body parts of human beings. The words are derived from Indonesian language, Javanese language, English, or a mixture of two or more languages.

\section{Language Style}

In everyday conversation, the community of Street Children tend to 
use metaphor and metonymy to communicate their intentions. The purpose and the use of this style of language is to keep their intentions from others; outsiders will not understand the real message of the conveyed words.

Metaphor

Metaphor is a kind of analogy that compares two entities directly in a short way along with using the words that already exists in everyday life. In other words, metaphor is the use of words or other expression to describe objects and conception which is based on figurative style, for example kaki meja (foot of table) is a comparison to the figurative style of human feet.

From the conducted research, there are some words which comprise some words of metaphor. Metaphor can be found in the form of living beings and inanimate objects.

The metaphor in a form of inanimate objects takes the reference of inanimate objects to describe a situation or similar circumstances. The examples of this kind of metaphor of inanimate objects can be seen in the data [24] below.

(24) P : "Oalah, cangkirmu kuwi lho, waton mangap..." (your cup, it just talks and talks...)

MT:"Cangkirmu dhewe! Mbok rasah misuh ngana kuwi, marai dosa lho! Tenan kuwi." (It's your own cup! End up your swearing, it is a sinful acts! I am serious)

The above data contains inanimate metaphor. It describes about the word cangkirmu or "your Cup". The word "Cup" in the context of the community of Street Children in Klaten terminal designated to symbolize "human mouth", since "the mouth of the cup" resembles the human 
mouth. The word cangkir or "cup" has become a special vocabulary that is often used to communicate among the street singers in the community to replace the usage of the word mouth. This type of metaphor is intended to make it more polite instead of the use of the word cangkem or cocot; the Javanese words to describe human mouth which is belong to the words of insult and profanity.

The other metaphors found in the community of Street Children take living things and the referents are animal or beast. The metaphors are frequently used to express anger. The examples of these metaphorical words are: asu-asu (dogs) and bajingan-bajingan (the bastards) to describe the stingy/miserly bus passengers when they were busking and there is no passenger who gives them money. The Javanese Metaphorical words Lawa ijo (Green bat) refers to street children who like to wear a big jacket with green color. A more details elaboration can be seen in the following data.

(25) $\mathrm{P}$ : "Wingi penumpange asu-asu, bajingan kabeh! Aku bengak-bengok ra ana sing ngeweki." (Yesterday the passengers are dogs, all bastards! I sung loudly but no one gave me money)

(25) P : "Sing arep munggah sapa?" (Who is supposed to get in the bus now?

MT:"Kudune lawa ijo" (it should be green bats).

(26) MT2: “Aku munggah sik yo, kae AJ teka. Muga-muga wae isine dudu asu-asu" (I'll get in the bus first, that's the AJ is coming. I hope its passengers are not dogs.)

Metonymy

Metonymy is the use of a name to describe another object which has particular associations or its attributive functions (Kridalaksana, 
2001: 137). This style of language is also used to give reference towards the street children of bus terminal who have specific features or characterization. For instance saying them as Lawa Ijo (green Bats), Bagong, etc. A more detailed elaboration can be seen in the data (27).

(27) P : “Awas lho dishooting, sesuk dilebokake tipi.” (Look out ! you're being televised at now, tomorrow you'll be on TV news)

MT : "Sing metu dhisik lawa ijo, hahahaha...." (The first portrayal should be the green bat, hahahaha (laughing) ....)

P : "Rak, sing metu kowe kuwi lho. Rupamu rak kaya grandong, dadine apik nak dilebokke tipi" (No, you'll first come up. Your face is like bad monster. It's suitable to be on TV news)

MT : "Dapurmu kuwi sing kaya grandong, hahaha...." (your kitchen (face) is the more suitable to be like bad monster, hahaha (laughing)....)

The Javanese lexicon lawa ijo (the geen bat) refers to a Street Children who have the characteristics of liking or frequently using the attributes of green jacket or shirt. The word Grandong is used to describe the street children who have a pockmarked face. This was taken from television portrayals about Grandong which has horrible or creepy face.

\section{Specific vocabularies of street children}

In general, particular lexicons used by community of Street Children is a vocabulary that has to do with the activity of the community. Practicaly, the community of the Street Children choose certain words with specific meanings (isomorphic). The existence of 
some different meaning is added to the lexical meaning of a word as the agreement of the community of Street Children.

Based on the collected data, the expression of Street Children in Klaten bus terminal consists the units of lingual words and phrases. The lingual unit is a word which is able to stand alone and created from free morphemes or the combination of free and bound morphemes. To understand the linguistic behavior, it is inseparable with the context and accompanying circumstances. These are the particular lexicons of Street Children community:

(28) P : “Ooo...dasar gentholet! Gondes, kowe!”(Ooh you're such a criminal)

(29) MT : "Kowe arep munggah ra, yu?" (you will get in the bus, won't you, sister?"

$\mathrm{P}$ : "Rasah nyangkir, wayahe munggah ya munggah. Nak pengin dhisik, ya munggaha!" (Don't talk too much (a cup), I will get in the bus on just get in the bus. If ythe proper time. If you want to go first, please!'

MT :"_ampak, nak ngana aku tak sik yo, yu? Kowe ngentenana limang-limang menit engkas. "'Yes, if it is like that I will go first, sister? You just wait for five minutes '

P : “_ampak kana dhisika, mengko nak ketangkep $\underline{\text { PII }}$ rasakna!" (Well, you may go there at first,you may feel misery if suddenly you have been caught by PII!)

The word Gentholet in the data (28) is an acronym of Gentho Klelat-Klelet (a lazy criminal). This refers to Street Children who are lazy to work. The word Gondes is an acronym of the words used to describe long-haired criminal who has weird-looking and are identical to those who belong to criminal or underworld people.

The word munggah (get in) refers to the activity of Street Children 
especially the street singers to start singing and offer their songs from bus to bus. The lingual unit of nyangkir" (a cup) refers to a person who talks too much. Whereas, the word PII is the abbreviation of Preman IrengIreng (criminals in black). PII is the term to describe the officials or police officers who is in charge to arrest street singers.

(30) MT : "Karo bala dhewe, masak kudu mbayar, bro!" (You're my own friends, will you ask me to pay, brother?)

(31) P : "Kok wajahe kabeh wajah romusa kabeh ngana!” (Why all of their faces look like romusha (slaves when Japan occupied Indonesia)?)

(32) MT : "Sing metu dhisik lawa ijo, hahahaha...." (The first portrayal should be the green bat, hahahaha ....")

P : "Rak, sing metu kowe kuwi lho. Rupamu rak kaya grandong, dadine apik nak dilebokke tipi" (No, you'll first come up. Your face is like bad monster. It's suitable to be on TV news)

(33) $\mathrm{P}$ : "Kae Langen radha sela, takmunggah kae wae we. Lumayan nak entuk kena nggo nothol ro nggo tuku handphone black berry.." (That Langen (bus) has somewhat less space, I'll take that. It's not bad if I can get it, I can afford to eat and buy blackberry")

The word bala dhewe (friends) refers to express the feeling of one family in the community of Street Children in the Klaten bus terminal. Meanwhile, the word romusha is used by the community of street children to describe people or bus passengers who have horrible or sinister face.

The word lawa ijo (green bat) refers to street children who have the hobby of wearing big zine and green (baggy) shirt or jacket. The word nothol is used to describe eating activity. The word nothol is belonging to 
rude words and usually refers to the activing of feeding animals.

(34) MT: "Kantong jatahe kapan?” (When Kantong (shack) will get his turns?)

P : "Puteran kedua paling" ((he) maybe will get the second round)

(35) P : "Oalah, cangkirmu kuwi lho, waton mangap..." (Oalah, watch your cup (mouth), don't just speak up......"

MT : "Cangkirmu dhewe! Mbok rasah misuh ngana kuwi, marai dosa lho! Tenan kuwi" ('Your own cup (mouth). It is better not to say bad words like that, it is a sin! I am serious.)

The word jatah (turns) and puteran (round) has almost similar meaning. What distinguishes them depends on the context with whom (the person) the speaker talk to. The word puteran has side by side meaning to the amount or the number of frequencies of the street singers have an opportunity to sing. In addition, the word cangkir (cup) is a word used by the community to replace the word of mouth.

(36) MT2 : "Aku munggah sik yo, kae AJ teka. Muga-muga wae isine dudu asu-asu" (I'll get in the bus first, that's the AJ is coming. I hope its passengers are not dogs anymore)

(37) MT1 : "Aku operasi jam pira, ya? Antrine isih ngulo, ya" (when I'll get my turn to do my job? What a long queue,huh)

$\mathrm{P} \quad$ : "Sabar lik, lagi wae mudhun kok wis arep munggah meneh" (Be patient, uncle. You've just get off the bus then you want to get in again)

MT3 : "Ngoyak setoran nggo apa, kok mempeng temen?" (you're so laborious in achieving the target of payment, why is that so?)

The lingual unit of munggah describe the very beginning of the singing activity from bus to the bus which is carried by the community of 
street children, especially the street singers. The antonym of munggah (get in) is mudhun (get off). They are used to indicate if the singers had finished singing from the bus. The word operasi in the street singer context is used to describe the activity to sing, whereas the word ngulo (it is like a snake) is used to describe long queue to get gturn. Furthermore, the word setoran is used to describe the target payment or money which must be paid to the treasurer of the community of Street Children.

\section{Conclusion}

The main conclusions drawn as the results of data analysis and discussion dealing with the language behavior of street children community in the Klaten bus terminal are: First, the social environment of the community of street children can not be separated from the diversity of oral language. The use of variety of different oral languages indicated by the the existing characteristics like: shortening, acronyms and abbreviations that can not be separated from the activities of street children of bus terminal and language behavior of the various cultural faced by street chldren community which lead to code mixing and cosde switching.

Second, the verbal interaction found in the community of street children can not be separated from the community of street children themselves or by others or new people who are not part of that community. The visible verbal interaction in the community is dominated by rude, profane and insult language. Meanwhile, in the choice of languages, most of them prefer using Javanese ngoko (low level or informal), and they will switch to speak in Bahasa when they deal with outsider or not the member of the community of street children. Besides, 
the linguistic behavior of street children also tend to use metaphor and metonymy in communicating with others. There are some specific lexicons found in the community of street children such as: gentholet, gondes, cangkir, PII, mudhun, munggah, bala dhewe, Asu-Asu, Wajah Romusha, Setoran, Ngulo, Lawa Ijo, Grandong, Puteran, Jatah, and others.

\section{References}

Chaer, Abdul dan Leonie Agustina. 1993. Sosiolinguistik Perkenalan Awal. Jakarta: Rineka Cipta.

Depdikbud. 1995a. Teori dan Metode Sosiolinguistik I. Jakarta: Pusat Pembinaan dan Pengembangan Bahasa. . 1995b. Teori dan Metode Sosiolinguistik II. Jakarta: Pusat

Pembinaan dan Pengembangan Bahasa.

Dwi Purnanto. 2001. Register Pialang Kendaraan Bermotor: Studi

Pemakaian Bahasa Kelompok Profesi di Surakarta (Tesis).

Surakarta: Sebelas Maret University Press.

Gorys Keraf. 2000. Diksi dan Gaya Bahasa. Jakarta: PT Gramedia Pustaka Utama.

Gumperz, John.1971. Language in Social Groups: Essays by John J. Gumperz (selected and introduced by Anwar S Dil). California: Stanford University Press.

Harimurti Kridalaksana. 2001. Kamus Linguistik. Jakarta: PT. Gramedia pustaka Utama.

Kundharu Saddhono. 2004. Etnik Madura, Perspektif Integrasi Linguistis Kultural. Surakarta: Pustaka Cakra.

Markhamah. 2000. Etnis Cina: Kajian Linguistis Kultural. Surakarta: Universitas Muhammadiyah Press.

Ohoiwutun, Paul. 2002. Sosiolinguistik: Memahami Bahasa dalam Konteks Masyarakat dan Kebudayaan. Jakarta: Kesaint Blanc.

Shalahuddin, Odi. 2000. Anak Perempuan Jalanan. Semarang: Yayasan Setara.

Sudaryanto. 2001. Metode dan Aneka Teknik Analisis Bahasa. Yogyakarta: Duta Wacana University Press. 
Sumarsono dan Paina Partana. 2004. Sosiolinguistik. Yogyakarta: Pustaka Pelajar.

Sutopo, H.B. 2002. Metodologi Penelitian Kualitatif: Dasar Teori dan Terapannya adalam Penelitian. Surakarta: Sebelas Maret University Press.

Suwito. 1987. Berbahasa dalam Situasi Diglosik: Kajian tentang Kendala Pemilihan Bahasa dan Pemilahan Bahasa di dalam Masyarakat Tutur Jawa di Tiga Kelurahan Kotamadya Surakarta (Disertasi). Jakarta: Universitas Indonesia.

. 1993. Sosiolinguistik: Sebuah Pengantar. Surakarta: Sebelas Maret University Press. .1997. Sosiolinguistik: Pengantar Awal. Surakarta: Fakultas Sastra Universitas Sebelas Maret.

Triyoga Dharma Utami. 2004. Pemakaian Bahasa Komunitas Pedagang Etnik Jawa dengan Mitra Tutur Etnik Jawa dan Non-Jawa di Pasar Klewer Sala (Kajian Sosiolinguistik). Surakarta: Universitas Sebelas Maret.

Troike, Murriel Saville. 1989. The Etnography of Communication. Oxford: Basil Blackwell.

Usdiyanto. 2003. Register Militer: Kajian Sosiopragmatik (Studi Kasus di Sekolah Menengah Umum Taruna Nusantara Magelang). Tesis. Surakarta: Sebelas Maret University Press.

Wardaugh, Ronald. 1988. An Introduction to Sociolinguistics. Oxford: Basil Blackwell. 